2020-04-15

Using ecosystem service assessments to support participatory marine spatial planning

Friedrich, LA

http://hdl.handle.net/10026.1/16027

10.1016/j.ocecoaman.2020.105121

Ocean \& Coastal Management

Elsevier BV

All content in PEARL is protected by copyright law. Author manuscripts are made available in accordance with publisher policies. Please cite only the published version using the details provided on the item record or document. In the absence of an open licence (e.g. Creative Commons), permissions for further reuse of content should be sought from the publisher or author. 


\title{
Using ecosystem service assessments to support participatory marine spatial planning
}

Friedrich LA, Glegg G, Fletcher S, Dodds W, Philippe M, Bailly, D Ocean and Coastal Management, 2020

\begin{abstract}
With growing interest in ocean uses for sustainable economic development, there is an increasing need for cross-sectoral marine spatial planning to balance different resource uses and conservation requirements. Ecosystem service assessments can provide the evidence to inform marine spatial planning decisions. Existing case studies suggest that these assessments can also have positive effects on the engagement of marine stakeholders in management and planning processes. Stakeholder engagement is a central element in marine spatial planning and other area-based management approaches. However, in a marine context, engagement is often difficult due to the lack of clear boundaries in the ocean, traditionally sectoral marine management and limited understanding of marine ecosystems. The study presented here investigated ecosystem service assessments as a tool for improving marine stakeholder engagement. Stakeholder experiences with ecosystem service assessments in six marine management and planning case studies were analysed to identify why, how and under what conditions ecosystem service assessments can support effective engagement. The findings show that under the right conditions, ecosystem service assessments can provide an inclusive and integrative platform for engagement, enable a better understanding of marine ecosystems, human-ecosystem interactions and management contexts, and support better stakeholder relationships. Stakeholder participation also improves the evidence base for ecosystem service assessments. Thus, involving stakeholders in ecosystem service assessments can improve marine spatial planning decisions and lead to better management and conservation outcomes for the ocean.
\end{abstract}

Keywords: Ecosystem service assessment; stakeholder engagement; stakeholder participation; marine spatial planning; area-based management.

\section{Introduction}

Ecosystem service assessments provide a framework for identifying trade-offs between natural resource use and conservation. These assessments can provide evidence for area-based marine management and planning approaches, such as marine spatial planning (Beaumont et al. 2017, Böhnke-Heinrichs et al. 2013, Börger et al. 2014). In particular where conflicts exist between different activities and conservation needs, ecosystem service assessments can help to identify priorities and balance interests for 
sustainable resource use and effective conservation. One common feature of many ecosystem service assessments is the involvement of stakeholders (Beaumont et al. 2017, Martin-Ortega et al. 2015). Experiences from various environmental policy contexts suggest that involving stakeholders in the assessment of ecosystem services can also have positive effects on the wider engagement of these stakeholders in management and planning processes (e.g. Beery et al. 2016, Berghöfer et al. 2016, Cork and Proctor 2005, Kushner et al. 2012, Slootweg and van Beukering 2008, van Beukering et al. 2008).

Stakeholder engagement is a key principle of ecosystem-based marine management (Ritchie and Ellis 2010, UNEP 2011), and a central element in most area-based management approaches, including marine spatial planning (Douvere and Ehler 2009, Gilliland and Laffoley 2008). Effective stakeholder engagement in management:

- improves access to local knowledge,

- enables representation of all relevant interests,

- increases accountability and transparency of decision-making,

- reduces stakeholder conflicts, and

- helps secure support for management decisions (Fiorino 1990, Richardson and Razzaque 2006, Rowe et al. 2008).

Thus, stakeholder engagement can improve marine spatial planning outcomes by enabling more legitimate, better informed decisions and increasing the effectiveness of management measures (Dalton 2005, Gleason et al. 2010, Pomeroy and Douvere 2008).

However, in a marine context, effective engagement is often difficult. The lack of clear physical and jurisdictional boundaries, and fragmented management structures, make it difficult to identify relevant stakeholders (Maguire et al. 2012, Ritchie and Ellis 2010, Sutherland and Nichols 2006). Traditionally sectoral management approaches have resulted conflictual relationships between different stakeholder groups (Douvere and Ehler 2009, Maguire et al. 2012, Mason et al. 2015; Fleming and Jones 2012). Moreover, there is often a lack of understanding of the connectivity, dynamic complexity and biological diversity in the marine environment, or the role of marine ecosystems in supporting human wellbeing (Jefferson et al. 2014, Jones 2002, Rose et al. 2008, Steel et al. 2005).

With growing interest in ocean uses for sustainable economic development, there is a need for integrated, cross-sectoral marine spatial planning. To improve marine spatial planning outcomes, it is important to find ways for supporting more effective marine stakeholder engagement. Marine management case studies suggest that participatory 
ecosystem service assessments can foster constructive dialogue and collaboration between stakeholders and managers (Kushner et al. 2012, van Beukering et al. 2008). In other environmental management contexts, ecosystem service assessments have helped identify relevant stakeholders, provided opportunities for stakeholder contributions to decision-making, and facilitated a shared understanding of management issues (Berghöfer et al. 2016, Cork and Proctor 2005, Slootweg and van Beukering 2008).

This paper explores the opportunities and challenges of using ecosystem service assessments to improve participatory marine spatial planning. Understanding why, how, and under what conditions, ecosystem service assessments can facilitate participatory processes enables more effective use of assessments to improve marine stakeholder engagement. The paper addresses three key questions: 1) What are the characteristics of ecosystem service assessments that facilitate engagement? 2) How do ecosystem service assessments contribute to effective engagement? 3) What are the enabling factors and obstacles for this?

\section{Methods}

\subsection{The case studies}

The paper draws on six case studies from the United Kingdom (UK) and France (Figure 1). These were part of a project that explored how ecosystem service assessments could improve marine management and planning in the English Channel. The sites were selected to reflect different governance frameworks and marine ecosystems. 


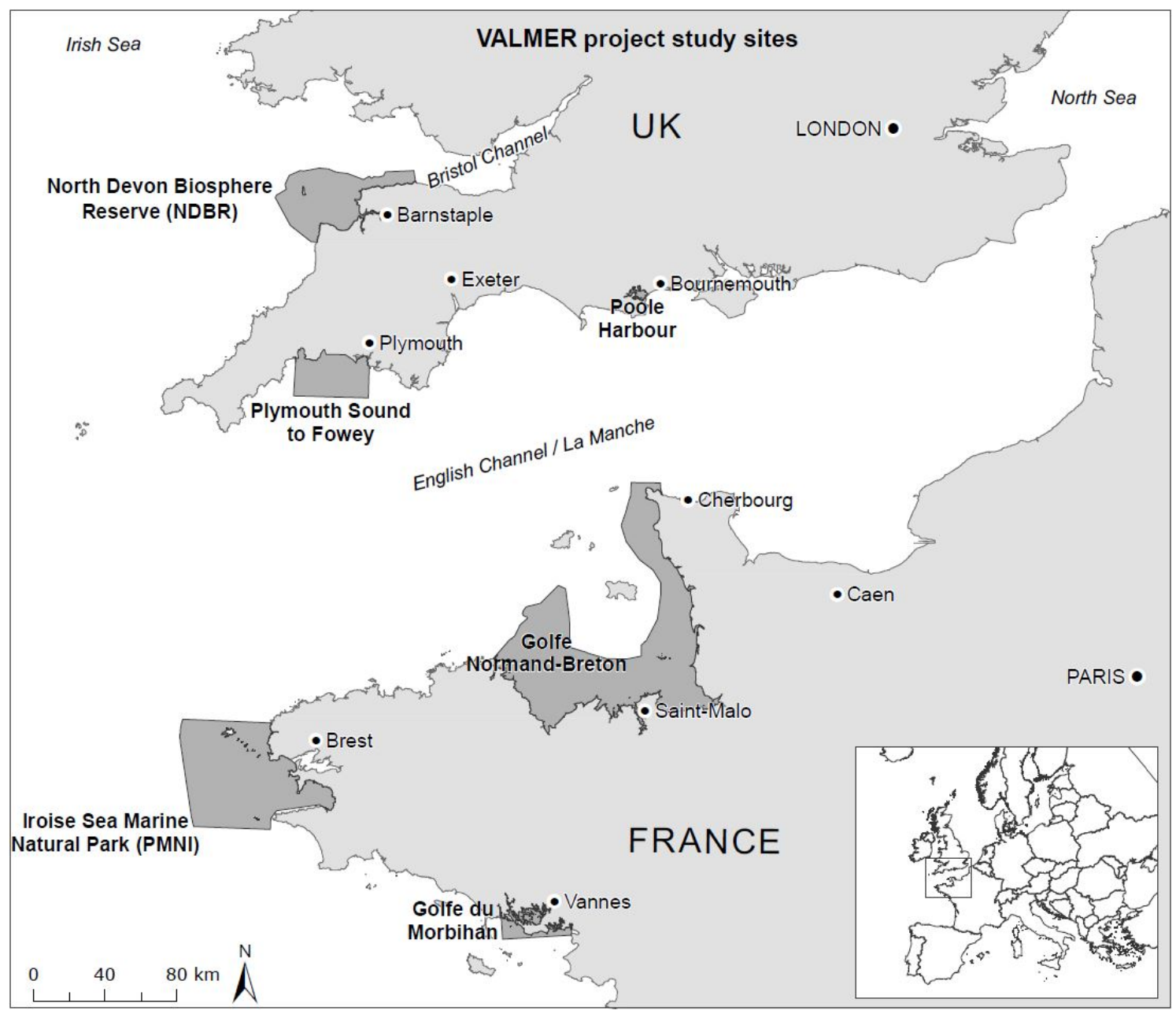

Figure 1: A map of the six case study sites (illustrated in dark grey). In the UK: Poole Harbour, North Devon Biosphere Reserve, Plymouth Sound to Fowey. In France: Golfe Normand Breton, Golfe du Morbihan, Iroise Sea Marine Natural Park (Source: Marine Biological Association, VALMER project)

At each site, a local stakeholder group participated in the case study process (Figure 2). The first step was the identification of a relevant management issue. Next, an ecosystem service assessment was undertaken with the stakeholders, who contributed their knowledge and validated the data used for the assessment. In parallel, the stakeholders participated in a scenario building exercise for alternative management options. The resulting management scenarios were combined with the ecosystem service assessment outputs. This informed a discussion in the stakeholder group on how ecosystem service assessments could inform local management decisions or action plans.

The case studies differed in terms of ecosystem service assessment methods, stakeholder group composition and degree to which the stakeholders were actively involved in the process (Beaumont et al. 2017, Dodds and Friedrich 2015) (Table 1). 


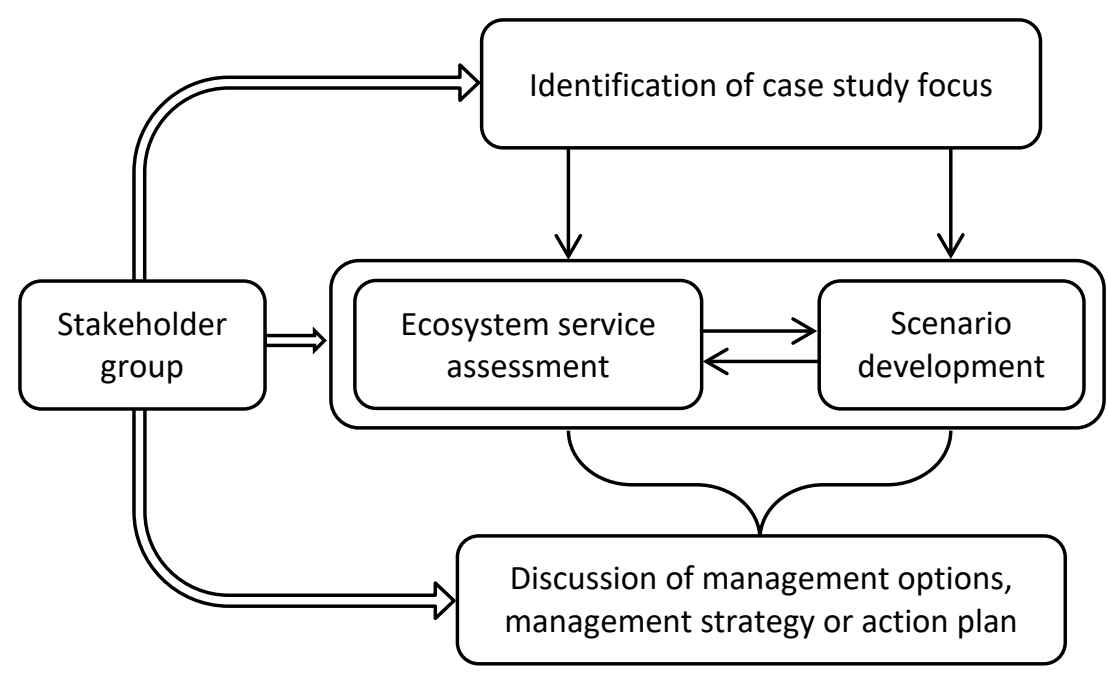

Figure 2: Simplified illustration of the case study process and involvement of the local stakeholder groups in the different steps of the process 
Table 1: Overview of the six case studies, including a summary of the ecosystem service assessment (ESA) focus and approach, stakeholder group and level of engagement at each site. Beaumont et al. (2017) describe the ESA methods used at each site in more detail.

\begin{tabular}{|c|c|c|c|c|}
\hline Case study site & $\begin{array}{l}\text { Ecosystem service } \\
\text { assessment focus }\end{array}$ & Ecosystem service assessment method & Stakeholder group & $\begin{array}{l}\text { Participation in ESA } \\
\text { and scenario building? }\end{array}$ \\
\hline \multirow[t]{2}{*}{ Poole Harbour, UK } & \multirow[t]{2}{*}{$\begin{array}{l}\text { Recreational use of the } \\
\text { harbour }\end{array}$} & $\begin{array}{l}\text { Travel cost method (monetary valuation based on } \\
\text { travel expenses) }\end{array}$ & \multirow{2}{*}{$\begin{array}{l}\text { Poole Harbour Steering Group (local } \\
\text { government authorities and statutory } \\
\text { bodies) }\end{array}$} & \multirow[t]{2}{*}{ No } \\
\hline & & $\begin{array}{l}\text { Public survey: prioritisation of environmental and } \\
\text { non-environmental factors }\end{array}$ & & \\
\hline \multirow[t]{2}{*}{ North Devon, UK } & \multirow{2}{*}{$\begin{array}{l}\text { Fisheries services, carbon } \\
\text { sequestration, nutrient } \\
\text { cycling (subtidal habitats) }\end{array}$} & Ecosystem service mapping and weighing & \multirow{2}{*}{$\begin{array}{l}\text { Biosphere Reserve Marine Working } \\
\text { Group (local authorities, organisations } \\
\text { and interest groups) and other local user } \\
\text { and interest groups }\end{array}$} & \multirow[t]{2}{*}{ Yes } \\
\hline & & $\begin{array}{l}\text { Bayesian belief networks (socio-ecological models } \\
\text { that measure changes in service provision under } \\
\text { different management scenarios) }\end{array}$ & & \\
\hline \multirow{3}{*}{$\begin{array}{l}\text { Plymouth to Fowey, } \\
\text { UK }\end{array}$} & \multirow{3}{*}{$\begin{array}{l}\text { Various services provided } \\
\text { by intertidal and subtidal } \\
\text { habitats }\end{array}$} & Habitat mapping & \multirow{3}{*}{$\begin{array}{l}\text { Managers and regulators with marine } \\
\text { and coastal responsibilities for the site }\end{array}$} & \multirow[t]{3}{*}{ Yes } \\
\hline & & Benefits transfer (values from comparable studies) & & \\
\hline & & Public survey: cultural benefits & & \\
\hline \multirow[t]{2}{*}{$\begin{array}{l}\text { Golfe Normand } \\
\text { Breton, France }\end{array}$} & \multirow{2}{*}{$\begin{array}{l}\text { Food provision (fisheries) } \\
\text { and recreational services } \\
\text { provided by tidal and } \\
\text { subtidal habitats }\end{array}$} & $\begin{array}{l}\text { Mapping of habitats, ecosystem functions and } \\
\text { services }\end{array}$ & \multirow{2}{*}{$\begin{array}{l}\text { Local managers, user and interest } \\
\text { groups involved in the development of a } \\
\text { marine park in the Golfe Normand } \\
\text { Breton }\end{array}$} & \multirow[t]{2}{*}{ Yes } \\
\hline & & $\begin{array}{l}\text { InVEST models (Integrated Valuation of Ecosystem } \\
\text { Services and Trade-offs) }\end{array}$ & & \\
\hline \multirow[t]{2}{*}{$\begin{array}{l}\text { Golfe du Morbihan, } \\
\text { France }\end{array}$} & \multirow[t]{2}{*}{$\begin{array}{l}\text { Various services provided } \\
\text { by seagrass beds }\end{array}$} & $\begin{array}{l}\text { Mapping of habitats, activities, benefits and } \\
\text { pressures }\end{array}$ & \multirow{2}{*}{$\begin{array}{l}\text { Local managers, user and interest } \\
\text { groups involved in the creation of a } \\
\text { natural park in the Golfe du Morbihan }\end{array}$} & \multirow[t]{2}{*}{ Yes } \\
\hline & & $\begin{array}{l}\text { Choice experiment (multi-criteria assessment } \\
\text { approach) }\end{array}$ & & \\
\hline Iroise Sea, France & $\begin{array}{l}\text { Food provision (fisheries) } \\
\text { and recreational services } \\
\text { provided by kelp forests }\end{array}$ & $\begin{array}{l}\text { Dynamic socio-ecological modelling (simulating } \\
\text { changes in service provision under different fisheries } \\
\text { management options) }\end{array}$ & $\begin{array}{l}\text { Local managers, user and interest } \\
\text { groups involved in the management of } \\
\text { the Iroise Sea Marine Natural Park }\end{array}$ & No \\
\hline
\end{tabular}




\subsection{Semi-structured interviews}

Semi-structured interviews were used to evaluate how the ecosystem service assessments had contributed to stakeholder engagement in the case studies. The questions were based on a set of normative criteria for effective engagement (Table 2). These 'good engagement' criteria were developed from existing engagement evaluation frameworks identified in the marine and environmental engagement literature (Dalton 2005, Fiorino 1990, Reed 2008, Rowe and Frewer 2000).

Table 2: Normative criteria for effective stakeholder engagement ('good engagement' criteria)

\begin{tabular}{ll} 
'Good engagement' criteria & How the criteria should be met \\
\hline Representativeness & Participation should be attractive and interesting to the stakeholders \\
\hline Inclusiveness & $\begin{array}{l}\text { All potentially affected and/or interested parties should be } \\
\text { represented }\end{array}$ \\
\hline Accessible information & $\begin{array}{l}\text { All participants should have opportunities to contribute and } \\
\text { participate }\end{array}$ \\
\hline Building capacity & $\begin{array}{l}\text { The participants should have access to easily understandable and } \\
\text { relevant information }\end{array}$ \\
\hline Dialogue and discussion & $\begin{array}{l}\text { Participants should be enabled to acquire the skills, knowledge and } \\
\text { confidence to participate and make informed decisions }\end{array}$ \\
\hline $\begin{array}{l}\text { Exchange of knowledge and } \\
\text { views }\end{array}$ & $\begin{array}{l}\text { The engagement process should be deliberative and interactive } \\
\text { knowledge and views }\end{array}$ \\
\hline $\begin{array}{l}\text { Integration of different } \\
\text { information and perspectives }\end{array}$ & $\begin{array}{l}\text { The engagement process should enable the integration of different } \\
\text { information and perspectives }\end{array}$ \\
\hline Trust and respect & $\begin{array}{l}\text { The engagement process should take place in an atmosphere of trust } \\
\text { and respect among all involved parties }\end{array}$
\end{tabular}

The stakeholders were asked 1) about their motivation for participating in the case study, 2) about their understanding of, and views on, the ecosystem services approach, 3) how these had changed through the case study, 4) what the case study had added to their site understanding, and 5) how they had found the experience of working with ecosystem service assessments. At the end of the interview, the stakeholders were asked to explain the terms 'ecosystem services' and 'ecosystem service assessment' to test their understanding of these concepts. At some sites, stakeholders were asked to explain 'ecosystem service valuation' instead of 'assessment' to account for differences in terminology used across the sites. The questions were adapted slightly for Poole Harbour and Iroise Sea, where stakeholders did not actively participate in the ecosystem service assessments or scenario exercises. Across the six sites, 39 interviews were conducted with stakeholders who had attended at least two case study events (Table 3). The interviews were conducted in English or French, either face to face or over the phone. 
Table 3: Overview of the 39 respondents, including number of stakeholders interviewed by site, and a breakdown of respondents by role and sector for each case study

\begin{tabular}{|c|c|c|c|c|}
\hline \multirow{2}{*}{$\begin{array}{l}\text { Case study } \\
\text { Poole } \\
\text { Harbour }\end{array}$} & \multirow{2}{*}{$\begin{array}{l}\begin{array}{l}\text { No. of } \\
\text { inter } \\
\text { views }\end{array} \\
4\end{array}$} & \multicolumn{2}{|c|}{ Description of respondents by site (number/sector) } & \multirow{2}{*}{$\begin{array}{l}\text { Stakeholder ID } \\
\text { PH2, PH3, PH4 }\end{array}$} \\
\hline & & 3 Public authority & $\begin{array}{l}\text { Local governance; navigation } \\
\text { management; nature conservation }\end{array}$ & \\
\hline & & 1 Commercial & Water management & PH1 \\
\hline \multirow[t]{4}{*}{$\begin{array}{l}\text { North } \\
\text { Devon }\end{array}$} & 9 & 3 Public authority & $\begin{array}{l}\text { Local governance; fisheries } \\
\text { management; nature conservation }\end{array}$ & ND2, ND3, ND8 \\
\hline & & $1 \mathrm{NGO} *$ & Nature conservation & ND7 \\
\hline & & 1 Commercial & Navigation management & ND9 \\
\hline & & 4 Interest group & Nature conservation; recreation & ND1, ND4, ND5, ND6 \\
\hline \multirow[t]{2}{*}{$\begin{array}{l}\text { Plymouth } \\
\text { to Fowey }\end{array}$} & 7 & 5 Public authority & $\begin{array}{l}\text { Local governance; fisheries } \\
\text { management; nature conservation }\end{array}$ & $\begin{array}{l}\text { PF2, PF3, PF4, PF5, } \\
\text { PF6 }\end{array}$ \\
\hline & & 2 NGO & Nature/heritage conservation & PF1, PF7 \\
\hline \multirow{2}{*}{$\begin{array}{l}\text { Golfe } \\
\text { Normand } \\
\text { Breton }\end{array}$} & 7 & 5 Public authority & $\begin{array}{l}\text { Local governance; fisheries } \\
\text { management; nature conservation }\end{array}$ & $\begin{array}{l}\text { GNB3, GNB4, GNB5, } \\
\text { GNB6, GNB7 }\end{array}$ \\
\hline & & 2 Commercial & Fisheries; renewable energy & GNB1, GNB2 \\
\hline \multirow[t]{3}{*}{$\begin{array}{l}\text { Golfe du } \\
\text { Morbihan }\end{array}$} & 8 & 4 Public authority & Local governance & $\begin{array}{l}\text { GdM2, GdM3, GdM5, } \\
\text { GdM7 }\end{array}$ \\
\hline & & 3 Commercial & Fisheries; recreation & GdM1, GdM4, GdM8 \\
\hline & & 1 Interest group & Recreation & GdM6 \\
\hline \multirow[t]{3}{*}{ Iroise Sea } & 4 & 1 Public authority & Area-based management & PNMI4 \\
\hline & & 2 Commercial & Fisheries & PNMI1, PNMI 2 \\
\hline & & $1 \mathrm{NGO}$ & Nature conservation & PNMI3 \\
\hline
\end{tabular}

\subsection{Interview analysis}

The interviews were analysed using a thematic approach (similar to Braun and Clarke 2006). The coding of responses was determined by the interview objectives and 'good engagement' criteria. Prominent and recurring themes were identified, and responses were compared between sites and stakeholder categories. Links between different themes were also explored. The results were organised into four categories, to assess if and how ecosystem service assessments contributed to good engagement experiences. The four categories were:

1) pre-case study knowledge of the ecosystem services approach,

2) challenges in understanding ecosystem service assessments,

3) factors that supported understanding of ecosystem service assessments,

4) ecosystem service assessments as a platform for exchange and learning. 
The results were then tested against the 'good engagement' criteria (see Table 2) to assess the contribution of the ecosystem service assessments to good engagement in the case studies. In a final step, the findings were synthesised into a framework for the use of ecosystem service assessments as a marine engagement tool.

\section{Results: stakeholder experiences with ecosystem service assessments}

\subsection{Pre-case study knowledge of the ecosystem services approach}

Across all six sites, about two thirds of the interviewed stakeholders had some pre-existing knowledge of the ecosystem services approach, while one third had not heard of it before. Almost all public authority and non-governmental organisation (NGO) stakeholders had some previous knowledge. For most commercial stakeholders and interest group representatives, ecosystem services and ecosystem service assessments were new concepts. Of the stakeholders who had heard of the ecosystem services approach before, about half did not know what exactly this implied. The others had a good understanding of ecosystem services as the resources, services or benefits that an ecosystem, or the environment, provides to humans. These were mainly NGO or public authority representatives. Their responses indicate that they have acquired their knowledge by working in environmental management and conservation. Their explanations largely reflected the definitions given in documents such as the UK National Ecosystem Assessment (UK NEA 2011) or the Millennium Ecosystem Assessment (MEA 2005). The stakeholders' understanding of ecosystem service assessments ranged from 1) assessments of ecosystem functioning and state, to 2) quantitative measurements and/or qualitative descriptions, and 3) monetary valuation. This reflects the lack of clear definitions and different methodologies for ecosystem service assessments in the literature.

\subsection{Challenges in understanding ecosystem service assessments}

Responses regarding understandability of the ecosystem service assessments in the case studies varied between sites. Key factors were to what extent the stakeholders were involved in technical aspects of the assessments, the terminology used and presentation of the assessments, and levels of pre-existing knowledge.

\section{Technical, complex and conceptual approach}

At two of the UK sites, the assessment methodologies were explained in detail and the stakeholders were asked for direct input at various stages. In Plymouth to Fowey, ecosystem services of intertidal and subtidal habitats were assessed using habitat mapping and benefits transfer (Richardson et al. 2015). In North Devon, socio-ecological models were used to assess 
fisheries services, carbon sequestration and nutrient cycling. At both sites, the stakeholders thought that the ecosystem services approach was very academic, technical and complex. Several North Devon stakeholders also mentioned that the first three workshops were particularly difficult to follow because they remained very conceptual. At the French sites, the stakeholders were not presented with the technical assessment details. Here, stakeholder input was gathered indirectly through expert meetings, thematic workshops and scenario exercises, without explicitly referring to the ecosystem service assessments. Consequently, most stakeholders did not comment on the understandability of the assessments. However, a few French stakeholders, who were familiar with the ecosystem services approach, made more general comments about the approach. Echoing the experience of the UK stakeholders, they described ecosystem service assessments as "quite complex, theoretical and technical" (GNB7, translated), "not easy to understand" (GdM2, translated), and "very scientific" (GdM5, translated).

\section{Limited familiarity with terminology, concepts and methods}

Stakeholders also said that the assessments were difficult to understand for people with no academic or scientific background. This was particularly evident in North Devon, where most participants had no previous knowledge of ecosystem services or methods like socioecological modelling, as illustrated by the following comments: "We had people who [...] have absolutely no background whatsoever of ecosystem services or mathematical modelling [...]." (ND4), and "it is harder for someone who doesn't deal with those sort of models every day to follow it" (ND1). The North Devon stakeholders also talked about ecosystem services "jargon" (ND4, ND8), suggesting that they did not find the terminology easily accessible. Moreover, they felt that limited time in the workshops and lack of adequate information material made it difficult to follow the assessment process. Stakeholders said that "[they] were being asked to absorb information that was highly conceptual in probably too short a time" (ND2) and that "[there] just wasn't enough time [...] to fully understand the methodology" (ND4).

\subsection{Factors that supported understanding of ecosystem service assessments}

Despite these challenges, the explanations of ecosystem services and ecosystem service assessments in the interviews revealed that most stakeholders with little or no previous knowledge gained a better understanding of the approach through the case studies. Only eight commercial and recreational stakeholders did not improve their understanding. The stakeholders mentioned several factors that helped them understand the ecosystem services concept and assessments. 


\section{Scenario exercises}

In the case studies, the ecosystem services approach was combined with scenario building. Comments suggest that the stakeholders found the scenario exercises helpful in making the ecosystem service assessments tangible and relevant, and thus understandable. In North Devon, the stakeholders talked positively about the final workshop, in which the assessment results were discussed in the context of the management scenarios. This helped them understand how ecosystem service assessments could be applied in decision making. In contrast, the first three workshops were difficult to follow because they remained conceptual.

\section{Tailored communication and pre-existing knowledge}

The importance of tailoring the presentation of ecosystem service assessments to the audience became apparent across sites. This included using familiar concepts and vocabulary, as well as adapting the information "to the level of knowledge and understanding of the audience" (GdM8, translated). One Golfe Normand Breton stakeholder summarised this by saying: "The [project] team managed to communicate concepts that were quite complex, theoretical and technical in a comprehensible and accessible way to stakeholders that are not usually in contact with these kinds of concepts [...]." (GNB7, translated).

Previous knowledge of the ecosystem services approach, and an academic or scientific education, were identified as factors that support understanding of ecosystem service assessments. In Plymouth to Fowey, all stakeholders had heard of ecosystem services before and some had a scientific background. This facilitated their understanding of the assessment, as suggested by the following comment: "I have got scientific training, [...] that probably helped." (PF4). In North Devon, in contrast, most stakeholders had no previous ecosystem services knowledge and found the assessment difficult to understand. Stakeholders in the Golfe du Morbihan also picked up on the importance of having information tailored to the local context: "The information given in the workshops was comprehensible because it was related to a concrete habitat and subject." (GdM2, translated). Similarly, stakeholders in Plymouth to Fowey mentioned that applying ecosystem service assessments at a small scale to locally relevant topics helped them "get [their] head around it a lot more easily [...]" (PF7).

\section{Commitment to the process}

Lastly, some stakeholders pointed out that ecosystem service assessments are a process and understanding them requires commitment to participate in each step. For example, one stakeholder said: "Perhaps if you had turned up to some of the latter meetings, maybe you wouldn't have had the background to have understood; you needed the whole picture." (PF2). 
The stakeholders were asked about their reasons for participating in the case studies. The responses show that interest in the ecosystem services approach was a motivating factor for representatives from NGOs, public authorities and the renewable energy sector. Conversely, other commercial and interest group stakeholders were not motivated by the ecosystem services approach.

\subsection{Ecosystem service assessments as a platform for exchange and learning}

The stakeholders from the four case studies with active participation ${ }^{7}$ were asked how they found the experience of working with ecosystem service assessments. Three key themes emerged.

\section{1) Open exchange and better mutual understanding}

Stakeholders at all four sites commented positively on the mix of sectors, good dialogue and interesting exchange at the workshops. They noted that the case study participants "were from a massive range of work areas and backgrounds" (PF4), bringing together people who do not normally meet. The stakeholders found it "useful and interesting" (ND7) to have representatives from different sectors and disciplines in the workshops that contributed different perspectives to the discussions. As one French stakeholder said, "[it] led to many interesting discussions because every stakeholder had a different point of view and it was interesting to have an exchange with the other stakeholders" (GdM1, translated).

Across the case studies, stakeholders referred to the ecosystem services approach with words like 'academic', 'scientific', 'neutral', 'objective', 'rational', 'fact based' or 'evidence based'. The repeated mention of this in the interviews indicates that the perceived neutrality of the ecosystem service assessment contributed to encouraging open dialogue and exchange between different stakeholders in the workshops. Some stakeholders commented that, through the exchange with others, the ecosystem services approach supported a better understanding among different sector representatives. For example, UK stakeholders said that it was useful "in terms of understanding potential impacts on different stakeholders" (ND7), "[everyone] was learning a bit more about the other side of things [...]" (ND1), and they "got a better feeling for what other people's drivers were" (PF2). In France, stakeholders said that the ecosystem services approach "allowed [them] to take into consideration the views of other stakeholders" (GNB7, translated), and helped "getting to know the different stakeholders [...] and their perspectives [...]" (GNB4, translated).

\footnotetext{
${ }^{7}$ North Devon, Plymouth to Fowey, Golfe Normand Breton, Golfe du Morbihan
} 


\section{2) Better and shared site understanding}

Another point raised in the interviews was that the assessments enabled the stakeholders to gain a more comprehensive view and better understanding of their sites. This included a better understanding of marine ecosystems, interactions between ecosystems and human activities, as well as interactions between different activities. For example, stakeholders commented that the ecosystem service assessments "explain[ed] how an ecosystem works and what you get from it" (ND1), and helped them gain a better understanding of "how the different activities are linked with each other and the environment" (GNB4, translated). Referring to the interactions between ecosystems and human activities, one stakeholder said: "[l gained] a better understanding of the Golfe Normand Breton because ecosystem service assessment is an approach that provides a comprehensive view and an understanding of how the different activities are related to the ecosystem services." (GNB1, translated). Linked to a more comprehensive view and improved understanding, stakeholders also pointed out the potential of ecosystem service assessments to foster innovative solutions. This is illustrated by comments that the ecosystem services approach offers "new ways of looking at old problems" (PF3) and enables "those sectors or groups who may have become entrenched in their views [...] to get the bigger picture" (PF3).

The potential of the ecosystem services approach to foster a shared and improved understanding of marine ecosystems, human-ecosystem interactions and different user perspectives, was also recognised at the two sites with no active engagement. One Iroise Sea stakeholder thought that an ecosystem service assessment "can improve the dialogue between different user groups [...] because it gives everyone the same level of understanding on a topic" (PNMI2, translated). In Poole Harbour, the assessment led the local management steering group to start a dialogue with recreational user groups that they had not previously spoken to, and to engage them in the management of the harbour. Through the assessment, the steering group also gained a better understanding of "what the other users find valuable in the harbour" (PH1) and "the value that people held on the environment" (PH4). This helped identify and resolve some of the conflicts between different recreational user groups in the harbour.

\section{3) Inclusiveness}

Another factor through which ecosystem service assessments supported good dialogue and open exchange, was by enabling inclusive engagement. Stakeholders commented on the fact that the assessments provided opportunities for everyone to contribute and allowed the integration of different knowledge, information and views. For example, stakeholders said that there were equal opportunities for everyone "to feed into the process" (PF2), that "[...] 
the different strands of information were all represented" (ND3), and "local knowledge was being valued and incorporated" (ND4). Besides the ecosystem service assessments, the scenario building exercises also provided opportunities and structure for exchange and input. Building on the improved understanding generated by the assessments, the management scenarios allowed the stakeholders to further explore the implications of different humanecosystem interactions at their sites. Comments show that this also contributed to gaining a better understanding of different stakeholder perspectives and roles. For example, one French stakeholder said: "The scenario approach was interesting because it shows [...] that all stakeholders [...] are responsible and can contribute to preserving ecosystem services." (GNB5, translated).

\subsection{Ecosystem service assessments and 'good engagement' criteria}

The interview results were tested against the set of criteria for effective engagement identified from the marine and environmental engagement literature (see Table 2). This revealed that in the six case studies the ecosystem service assessments contributed to most of the 'good engagement' criteria (Table 4).

Table 4: Summary of how the ecosystem service assessments (ESA) studies contributed to the 'good engagement' criteria in the six case

\begin{tabular}{|c|c|c|}
\hline $\begin{array}{l}\text { 'Good engagement' } \\
\text { criteria }\end{array}$ & $\begin{array}{l}\text { ESA } \\
\text { contribution? }\end{array}$ & How ESA contributed to the criteria in the case studies \\
\hline $\begin{array}{l}\text { Motivation to get } \\
\text { involved }\end{array}$ & In part & $\begin{array}{l}\text { ESA was a motivating factor for NGO and public authority } \\
\text { stakeholders; but not for commercial and recreational } \\
\text { stakeholders }\end{array}$ \\
\hline Representativeness & $\checkmark$ & $\begin{array}{l}\text { ESA provided a platform for different stakeholders, representing } \\
\text { all interests at a site, to come together }\end{array}$ \\
\hline Inclusiveness & $\checkmark$ & $\begin{array}{l}\text { ESA provided opportunities for everyone to contribute their } \\
\text { views and knowledge }\end{array}$ \\
\hline $\begin{array}{l}\text { Accessible } \\
\text { information }\end{array}$ & In part & $\begin{array}{l}\text { ESA was found to be very technical, complex, conceptual; but } \\
\text { scenario exercises, tailored communication and local focus } \\
\text { helped to understand ESA and the relevance for local governance } \\
\text { decisions }\end{array}$ \\
\hline \multirow[t]{3}{*}{ Building capacity } & $\checkmark$ & $\begin{array}{l}\text { ESA supported better and shared understanding of the site, its } \\
\text { human-ecosystem interactions and management context }\end{array}$ \\
\hline & & ESA supported better mutual understanding among stakeholders \\
\hline & & $\begin{array}{l}\text { ESA enabled people to look at things from a new perspective and } \\
\text { think outside the box }\end{array}$ \\
\hline $\begin{array}{l}\text { Dialogue and } \\
\text { discussion }\end{array}$ & $\checkmark$ & $\begin{array}{l}\text { ESA provided a neutral and inclusive setting for constructive } \\
\text { dialogue and open exchange }\end{array}$ \\
\hline $\begin{array}{l}\text { Exchange of } \\
\text { knowledge and views }\end{array}$ & $\checkmark$ & $\begin{array}{l}\text { Better shared and mutual understanding enabled and } \\
\text { encouraged open exchange and mutual learning }\end{array}$ \\
\hline
\end{tabular}




\begin{tabular}{lcl}
\hline $\begin{array}{l}\text { Integration of } \\
\text { different information } \\
\text { and perspectives }\end{array}$ & $\checkmark$ & $\begin{array}{l}\text { ESA enabled the integration of different knowledge, views and } \\
\text { interests into the decision-making process }\end{array}$ \\
\hline Trust and respect & Potentially & $\begin{array}{l}\text { Better dialogue and mutual understanding have the potential to } \\
\text { foster trust and respect }\end{array}$ \\
\hline
\end{tabular}

\section{Discussion}

The findings presented in Table 4 suggest that ecosystem service assessments can contribute to several key criteria for effective participatory processes. Going back to the questions raised at the beginning of the paper, these findings help explain why and how ecosystem service assessments can support effective stakeholder engagement in marine spatial planning and other area-based marine management approaches. The findings also reveal the main obstacles and enabling factors for realising this marine engagement potential.

\subsection{Why and how: the marine engagement potential of ecosystem service assessments}

The engagement potential of ecosystem service assessments can be summarised into three main elements.

\section{1) An inclusive and integrative platform for engagement}

Ecosystem service assessments provide an inclusive and integrative platform for representative participation. The assessments facilitate the integration of different types of information into planning and decision-making processes, including scientific evidence, sector specific expertise, local, traditional and indigenous knowledge. This enables all participants to contribute their knowledge and views in a meaningful way. It also helps ensure that all key interests are represented. Giving all relevant stakeholders an equal opportunity to take part in discussions and provide input into plans and decisions is an important element of effective engagement (Dalton 2005, Fiorino 1990, Rowe and Frewer 2000).

\section{2) Constructive dialogue, open exchange and mutual learning}

Ecosystem service assessments can facilitate constructive dialogue, open exchange and mutual learning among different stakeholders. The interviews revealed that marine stakeholders perceive ecosystem service assessments as neutral and objective, not focused on specific sectoral interests. It can be argued that this is a misconception as the process and results tend to be influenced by the views and beliefs of those who conduct the assessment (Berghöfer et al. 2016). However, the interview findings suggest that this perceived neutrality and objectivity contributes to encouraging open exchange and mutual learning. 
The case studies brought together stakeholders that do not usually interact or often have conflictual relationships. Despite this, stakeholders commented positively on the good dialogue and interesting exchange in the workshops. Cork and Proctor (2005) found that ecosystem service approaches support interdisciplinary dialogue and mutual learning among people from different backgrounds. The six UK and French case studies confirm that this also applies in the marine context, where historically there has been little cross-sectoral dialogue. As one French participant put it, "the discussion was very open, even with stakeholders with whom they would usually be in opposition" (GdM8, translated). In the Golfe Normand Breton, one stakeholder explained that marine consultation processes are often confrontational and ineffective as each group tends only to promote or defend their own interests; whereas, in the case study workshops, the ecosystem services approach "got different stakeholders with different interests to listen to each other" (GNB3, translated).

There are two factors that could explain the perceived neutrality of ecosystem service assessments. First, ecosystem service assessments are presented as a scientific approach, implying a degree of objectivity and impartiality. Moreover, in the case studies, the assessments were facilitated by independent researchers who had no vested interest in the sites. Scientific objectivity and impartiality are not unique to ecosystem service assessments. For example, they could also apply to environmental impact assessments. However, environmental impact assessments only consider human impacts on the environment while the ecosystem services approach takes a more holistic view of the system. The second, and possibly more relevant factor for the perceived neutrality of ecosystem service assessments is that they enable consideration of impacts and benefits for the environment, economy and society in one integrated framework. This holistic perspective also contributes to the third element of the engagement potential of ecosystem service assessments.

\section{3) Better understanding of human-ecosystem interactions and management context}

Ecosystem service assessments can contribute to constructive marine engagement by enabling a better and shared understanding of human-ecosystem interactions, marine management contexts and other stakeholders' perspectives. Ecosystem service assessments can provide a comprehensive and integrated view on a marine site and the human-ecosystem interactions within it. The case study evidence shows that this enables people to gain a broader understanding of their local marine ecosystem. It encourages them to look at familiar locations from different perspectives, beyond their own personal or professional interests. It also helps them better understand the interdependencies and interactions between different human activities. This further encourages people to share their knowledge and experiences and engage in open dialogue and discussion. 
Constructive dialogue and a more comprehensive understanding of human-ecosystem interactions also foster better mutual understanding among stakeholders. This enables them to develop a shared and improved understanding of the marine management context. For example, stakeholders from the Golfe du Morbihan talked about having " $a$ more comprehensive approach to the question of human-seagrass interactions, looking at all the different activities and uses" (GdM1, translated) and gaining "a better understanding of the interactions between the different activities [...] and seagrass" (GdM5, translated). Similarly, Cork and Proctor (2005) report that the ecosystem services concept helped the participants in their study gain a clearer understanding of the issues that were being addressed.

Thus, participation in ecosystem service assessments helps address two key challenges of effective marine stakeholder engagement: 1) limited understanding of marine ecosystems (Jones 2002, Rose et al. 2008, Steel et al. 2005), and 2) difficult relationships between different stakeholder groups (Douvere and Ehler 2009, Maguire et al. 2012, Mason et al. 2015). The interview findings suggest that involving stakeholders in ecosystem service assessments can help improve relationships and enable more constructive collaboration between stakeholders and managers. This would also explain the positive effects on stakeholder dialogue and engagement that were found in other marine case studies where ecosystem service assessments were used in participatory policy and management processes (Kushner et al. 2012, van Beukering et al. 2008). Furthermore, by encouraging and enabling people to share knowledge, consider things from new perspectives and think outside their usual boxes, participatory ecosystem service assessments also hold the potential to lead to better informed marine spatial plans and innovative management solutions.

\subsection{Obstacles to ecosystem service assessment-based engagement}

The interview findings also highlight three key challenges of effectively using ecosystem service assessments in participatory marine governance processes. The main difficulty is making ecosystem service assessments accessible to a non-expert audience. The ecosystem services approach is often assumed to be self-explanatory (Berghöfer et al. 2016). However, in the interviews, the stakeholders repeatedly said that it is very technical and conceptual, and difficult to understand for people with no academic or scientific background. In fact, ecosystem service assessments often involve modelling or valuation methods that can be quite complicated. Moreover, several stakeholders mentioned that the ecosystem services terminology is full of technical "jargon" (ND4; ND8). The theoretical nature and technical complexity of the ecosystem services approach can be limiting factors for the usefulness of ecosystem service assessments as participatory engagement tool (Beery et al. 2016, Dalton 2005, Rowe and Frewer 2000). 
The second obstacle is the limited familiarity of marine stakeholders with the ecosystem services concept, assessment methods and terminology. The interviews revealed that public authority and NGO representatives tend to have some knowledge of the ecosystem services approach. However, their understanding might be incomplete or different from that of the experts conducting the assessment. Conversely, commercial and recreational marine stakeholders were found to be largely unfamiliar with the ecosystem services approach. This poses a challenge, as the interviews suggest that previous knowledge, whether comprehensive or not, does facilitate understanding of ecosystem service assessments. This was also found by Beery et al. (2016), who note that applying ecosystem service assessments in management processes is difficult because of their academic nature, and that previous knowledge is required to understand them.

Consequently, enabling stakeholders to work with ecosystem service assessments requires regular and continuous engagement, for example through a series of sufficiently long workshops. It also requires commitment to participate in the entire process. This can present another challenge in marine management contexts. Marine stakeholders might be spread over large geographical distances, or their availability might depend on unpredictable weather conditions. This makes regular and continuous engagement difficult to implement.

\subsection{Enabling factors for ecosystem service assessment-based engagement}

Despite these obstacles, stakeholder experiences in the six case studies were largely positive. This was thanks to a number of factors that facilitated successful engagement with the ecosystem service assessments. These factors provide the conditions under which ecosystem service assessments can foster better understanding and constructive dialogue. From the stakeholders' reflections on the workshops, the following enabling factors were identified:

1. Interaction with other sectors plays a key role in developing a better and shared understanding in an ecosystem service assessment process. Through dialogue and exchange of knowledge and perspectives, the assessment becomes more tangible and relevant.

2. The ecosystem service assessment should be neutral and avoid promoting a specific sector or outcome (for example, conservation or development). Having scientific experts and external facilitators can help create a neutral and objective setting. This is an important prerequisite for enabling open exchange and mutual learning.

3. Stakeholders should have opportunities to actively participate in the ecosystem service assessment, for example by 1 ) validating existing data; 2) contributing information 
(including expert, local, traditional or indigenous knowledge); and 3) providing feedback on the assessment process and results. Besides securing a more complete evidence base for the assessment, the information from the stakeholders helps make the assessment relevant and understandable. Moreover, active involvement provides a catalyst for open exchange and mutual learning.

4. Any technical aspects of the ecosystem service assessment that stakeholders are involved in must be made accessible. Where needed, capacity development should be integrated into the participatory process to enable full engagement in assessment activities.

5. The practical relevance of the ecosystem service assessment within the marine spatial planning process needs to be clear. Scenario exercises can support this by illustrating how different planning options change the assessment outcomes. This helps overcome obstacles resulting from the novelty and complexity of the ecosystem services approach.

6. All information given to the stakeholders must be clear and understandable. This includes information about the ecosystem services approach, assessment methods, and any input to the assessment. Consideration should be given to the fact that pre-existing knowledge about ecosystem services is limited among marine stakeholders and can differ from expert understanding of the approach. Information about the ecosystem services approach should be tailored to the background of the participating stakeholders (questions to support this are: Do they have an academic background? Are they likely to have come into contact with the ecosystem services approach at work?). Technical or scientific jargon should be avoided or explained using familiar vocabulary and local ecosystem service examples.

7. Stakeholders should be enabled to participate in the full process. They should be taken through the assessment step by step, and sufficient time should be planned in for examples, questions, discussions and exercises. This is particularly important for building familiarity with the ecosystem services approach and capacity to understand and participate in the assessment.

These enabling factors describe the conditions under which ecosystem service assessments can effectively support and improve stakeholder participation in marine spatial planning. They can be summarised into a framework to guide the use of ecosystem service assessments as a marine engagement tool (Figure 3). 
Effective use of ecosystem service assessments as marine engagement tool

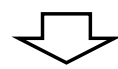

Participatory ESA process

Enabling factors:

- A mix of stakeholders from different sectors

- A neutral and objective process supported by independent experts

- Active involvement/participation in ESA discussions and activities (including: data validation, contribution of information, feedback on ESA process and results)

- Capacity building for technical aspects of ESA

- Exercises with practical relevance, for example integration of ESA in scenario building to explore different management alternatives

- Clear and understandable information (including: information about and evidence for ESA), tailored to the participants' background and preexisting knowledge, avoiding/explaining technical jargon, using familiar vocabulary and local examples

- Ensure participation in entire ESA process and plan sufficient time for explanations, questions, discussions and activities

Core engagement potential of ESA

Constructive dialogue and open exchange among stakeholders and with managers

ecosystem interactions, management context and different perspectives

ll

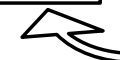

Figure 3: A framework of enabling conditions to guide the effective use of ecosystem service assessments (ESA) as an engagement tool in participatory marine spatial planning processes

\section{Conclusion}

Stakeholder engagement plays a key role in marine spatial planning and other area-based marine management approaches. However, effective marine engagement is often difficult, mainly due to conflictual relationships and limited understanding of marine ecosystems and management contexts. Studies from various environmental governance contexts have reported positive engagement effects of participatory ecosystem service assessments. The 
findings from the six case studies presented here confirm this for the marine context, providing answers to the questions 'what constitutes the engagement potential of ecosystem service assessments?', and 'what are the obstacles and enabling factors?'.

Under the right conditions, participatory ecosystem service assessments can address some of the key challenges of marine stakeholder engagement. Ecosystem service assessments provide an inclusive and integrative platform for engagement. The perceived neutrality and holistic approach of the assessments encourage constructive dialogue and open exchange. They enable a better understanding of marine ecosystems, human-ecosystem interactions, management contexts and differing perspectives. This positive exchange and improved understanding can support better stakeholder relationships. It can increase the legitimacy of decision making, reduce opposition to management plans and facilitate implementation of management and conservation measures.

By providing access to different types of knowledge, stakeholder participation also improves the evidence base for ecosystem service assessments. This is particularly relevant as these assessments are increasingly used to inform decisions about conflicting resource uses and conservation needs in marine spatial planning. Moreover, participatory ecosystem service assessments hold potential for innovation, as they introduce new perspectives and encourage 'out of the box' thinking. Thus, involving stakeholders in ecosystem service assessments can lead to better informed marine spatial plans and more effective management solutions.

In conclusion, this study shows how participatory ecosystem service assessments can support effective marine stakeholder engagement. It highlights how this can improve marine spatial planning and lead to better management and conservation outcomes for the ocean. Besides marine spatial planning, the framework could also support effective engagement and improved outcomes in other area-based management approaches, such as integrated coastal zone management or marine protected areas.

\section{Acknowledgements}

This work was carried out as part of the VALMER project (2012-2015), which was selected under the European cross-border cooperation programme INTERREG IV A France (Channel) England, co-funded by the European Regional Development Fund. The authors wish to thank all VALMER stakeholders for their time and contributions to the case studies. We are particularly grateful to everyone who took part in the interviews. Lastly, we would like to thank the VALMER case study teams for their support. 


\section{References}

Beaumont, N.J., Mongruel, R. and Hooper, T. 2017. Practical application of the Ecosystem Service Approach (ESA): lessons learned and recommendations for the future. International Journal of Biodiversity Science, Ecosystem Services \& Management 13(3):68-78. DOI: $10.1080 / 21513732.2018 .1425222$.

Beery, T., Stålhammar, S., Jönsson, K.I., Wamsler, C., Bramryd, T., Brink, E., Ekelund, N., Johansson, M., Palo, T. and Schubert, P. 2016. Perceptions of the ecosystem services concept: Opportunities and challenges in the Swedish municipal context. Ecosystem Services 17: 123130.

Berghöfer, A., Brown, C., Bruner, A., Emerton, L., Esen, E., Geneletti, D., Kosmus, M., Kumar, R., Lehmann, M., Leon Morales, F., Nkonya, E., Pistorius, T., Rode, J., Slootweg, R., Tröger, U., Wittmer, H., Wunder, S. and van Zyl, H. 2016. Increasing the policy impact of ecosystem service assessments and valuations - Insights from practice. Helmholtz-Zentrum für Umweltforschung (UFZ) GmbH, Leipzig, and Deutsche Gesellschaft für Internationale Zusammenarbeit (GIZ) GmbH, Eschborn, Germany.

Böhnke-Heinrichs, A., Baulcomb, C., Koss, R., Hussain, S.S. and de Groot, R.S. 2013. Typology and indicators of ecosystem services for marine spatial planning and management. Journal of Environmental Management 130: 135-145.

Börger, T., Beaumont, N.J., Pendleton, L., Boyle, K.J., Cooper, P., Fletcher, S., Haab, T., Hanemann, M., Hooper, T.L., Hussain, S.S., Portela, R., Stithou, M., Stockill, J., Taylor, T. and Austen, M.C. 2014. Incorporating ecosystem services in marine planning: the role of valuation. Marine Policy 46: 161-170.

Braun, V. and Clarke, V. 2006. Using thematic analysis in psychology. Qualitative Research in Psychology 3(2): 77-101.

Cork, S.J. and Proctor, W. 2005. Implementing a process for integration research: ecosystem services project, Australia. Journal of Research Practice 1(2): 1-25.

Dalton, T.M. 2005. Beyond biogeography: a framework for involving the public in planning of U.S. Marine Protected Areas. Conservation Biology 19(5): 1392-1401.

Dodds, W. and Friedrich, L.A. (Eds.) 2015. The potential role of ecosystem service assessment in marine governance in the western Channel. VALMER Work Package 4 evidence base report. VALMER project. 
Douvere, F. and Ehler, C.N. 2009. New perspectives on sea use management: initial findings from European experience with marine spatial planning. Journal of Environmental Management 90: 77-88.

Fiorino, D.J. 1990. Citizen participation and environmental risk: a survey of institutional mechanisms. Science, Technology and Human Values 15(2): 226-243.

Fleming, D.M. and Jones, P.J.S. 2012. Challenges to achieving greater and fairer stakeholder involvement in marine spatial planning as illustrated by the Lyme Bay scallop dredging closure. Marine Policy 36(2): 370-377.

Gilliland, P.M. and Laffoley, D. 2008. Key elements and steps in the process of developing ecosystem-based marine spatial planning. Marine Policy 32: 787-796.

Gleason, M., McCreary, S., Miller-Henson, M., Ugoretz, J., Fox, E., Merrifield, M., McClintock, W., Serpa, P. and Hoffman, K. 2010. Science-based and stakeholder-driven marine protected area network planning: A successful case study from north central California. Ocean and Coastal Management 53: 52-68.

Jefferson, R.L., Baily, I., Laffoley, D., Richards, J.P. and Attrill, M.J. 2014. Public perceptions of the UK marine environment. Marine Policy 43: 327-337.

Jones, P.J.S. 2002. Marine protected area strategies: issues, divergences and the search for middle ground. Reviews in Fish Biology and Fisheries 11: 197-216.

Kushner, B., Waite, R., Jungwiwattanaporn, M. and Burke, L. 2012. Influence of coastal economic valuations in the Caribbean: enabling conditions and lessons learned. Working Paper. Washington, DC: World Resources Institute.

Maguire, B., Potts, J. and Fletcher, S. 2012. The role of stakeholders in the marine planning process - stakeholder analysis within the Solent, United Kingdom. Marine Policy 36: 246-257.

Martin-Ortega, J., Ferrier, R.C., Gordon, I.J. and Khan, S. (Eds.) 2015. Water ecosystem services: a global perspective. Cambridge University Press, Cambridge, UK.

Mascia, M.B. 2003. The human dimension of coral reef marine protected areas: recent social science research and its policy implications. Conservation Biology 17(2): 630-632.

MEA 2005. Ecosystems and human well-being: synthesis. Millennium Ecosystem Assessment. Island Press, Washington, DC.

Pomeroy, R. and Douvere, F. 2008. The engagement of stakeholders in the marine spatial planning process. Marine Policy 32: 816-822. 
Reed, M.S. 2008. Stakeholder participation for environmental management. A literature review. Biological Conservation 141: 2417-2431.

Richardson, B.J. and Razzaque, J. 2006. Public Participation in Environmental Decision Making. Environmental Law for Sustainability: 165-194.

Richardson, L., Loomis, J., Kroeger, T. and Casey, F. 2015. The role of benefit transfer in ecosystem service valuation. Ecological Economics 115: 51-58.

Ritchie, H. and Ellis, G. 2010. A system that works for the sea? Exploring stakeholder engagement in marine spatial planning. Journal of Environmental Planning and Management 53(6): 701-723.

Rose, C., Dade, P. and Scott, J. 2008. Qualitative and quantitative research into public engagement with the undersea landscape in England. Natural England Research Reports, NERR019.

Rowe, G. and Frewer, L.J. 2000. Public participation methods: a framework for evaluation. Science, Technology and Human Values 25(1): 3-29.

Rowe, G., Horlick-Jones, T., Walls, J., Poortinga, W. and Pidgeon, N.F. 2008. Analysis of a normative framework for evaluating public engagement exercises: reliability, validity and limitations. Public Understanding of Science 17(4): 419-441.

Slootweg, R. and van Beukering, P. 2008. Valuation of Ecosystem Services and Strategic Environmental Assessment. Lessons from influential cases. Netherlands Commission for Environmental Assessment.

Steel, B.S., Smith, C., Opsommer, L., Curiel, S. Warner-Steel, R. 2005. Public ocean literacy in the United States. Ocean and Coastal Management 48: 97-114.

Sutherland, M. and Nichols, S. 2006. Issues in the governance of marine spaces. In: International Federation of Surveyors. Administering Marine Spaces: International issues. Copenhagen, Denmark: FIG publication. https://www.fig.net/pub/figpub/pub36/chapters/ chapter_1.pdf [accessed 26.01.2017]

UK NEA 2011. The UK National Ecosystem Assessment: Synthesis of the Key Findings. UNEPWCMC, Cambridge, UK.

UNEP 2011. Taking steps toward marine and coastal ecosystem-based management. An introductory guide. United Nations Environmental Programme Regional Seas Reports and Studies No. 189. 
van Beukering, P.J.H., Slootweg, R. and Immerzeel, D. 2008. Valuation of ecosystem services and strategic environmental assessment. Influential case studies. Netherlands Commission for Environmental Assessment. 